\title{
Comparison of Health Related Quality of Life between Type I and Type II Narcolepsy Patients
}

\author{
Jae Wook Cho ${ }^{1}$, Dae Jin Kim ${ }^{1}$, Kyoung Ha Noh ${ }^{1}$, Junhee Han ${ }^{2}$, Dae Soo Jung ${ }^{3}$ \\ ${ }^{1}$ Department of Neurology, ${ }^{2}$ Division of Biostatistics, Research Institute of Convergence for Biomedical Science and Technology, \\ Pusan National University Yangsan Hospital, Yangsan, \\ ${ }^{3}$ Department of Neurology, School of Medicine, Pusan National University, Busan, Korea
}

제I형과 제II형 기면증 환자의 건강 관련 삶의 질 비교

조재욱 ${ }^{1}$, 김대진 ${ }^{1}$, 노경하 $^{1}$, 한준희 $^{2}$, 정대수 ${ }^{3}$

부산대학교 양산병원 의생명융합연구소 신경과, ${ }^{1}$ 통계학과, ${ }^{2}$ 부산대학교 의학전문대학원 신경과 ${ }^{3}$

J Sleep Med 2016;13(2):46-52 / https://doi.org/10.13078/jsm.16009

We would like to correct the grant information as written below.

\section{Acknowledgments}

본 연구는 2015년도 양산부산대학교병원 임상연구비 지원으로 이루어졌음.

This is an Open Access article distributed under the terms of the Creative Commons Attribution Non-Commercial License (http://creativecommons.org/licenses/by-nc/4.0) which permits unrestricted non-commercial use, distribution, and reproduction in any medium, provided the original work is properly cited. 